\title{
The Effect of Teacher Scaffolding on Students' Paragraph Writing Skills in EFL Classroom: The Case of Grade Nine Students in Meneguzer Secondary School, Amhara Regional State, Ethiopia
}

\author{
Simachew Gashaye \\ Debre Markos University, Debre Markos, Ethiopia \\ Belyihun Muchie \\ Debre MarkosUniversity, Ethiopia
}

\begin{abstract}
This study was intended to examine the effect of teacher scaffolding on grade nine students' paragraph writing performance in Meneguzer secondary school, Amhara-Ethiopia. The study employed a quasi-experimental research design with explanatory sequential mixed methods of data collection and analysis. There were experimental and control groups of students including 40 students in each group. Test, questionnaire and interview were used to gather data. The quantitative data were analysed using an independent sample t-test, whereas the qualitative data were analysed thematically. The pre-test yielded a significant value of sig. (2-tailed) $=0.659$ which was higher than $\alpha=0.05$. This showed that both the experimental and the control groups of students were equal and homogenous in their writing performance before treatment. However, after the treatment, there was a significant difference between the writing performance of the students in the two groups as the analysis of writing test in post-test yielded sig. (2- tailed) $=0.025$ which was smaller than $\alpha=0.05$. This implies that the treatment enabled the participants in the experimental group to improve their writing skills. The result of the questionnaire and interview analyses further revealed that the experimental group of participants were motivated and initiated by the teacher scaffolding to improve their writing skills. Thus, it can be concluded that teacher scaffolding has a positive significant effect on students' writing skills. As a result, it motivates students to practice their writing skills independently.
\end{abstract}

Index Terms — scaffolding, teacher scaffolding, instructional technique, writing skill, and teacher support

\section{INTRODUCTION}

Writing ability in the second or foreign language has great importance for students' academic success. Durga and Rao (2018) claimed that it is a common means of communication that EFL learners should practice to be effective for academics and job requirements. Effective students in writing are always successful in expressing their ideas and attaining their goals.

In teaching writing, selecting appropriate writing tasks promotes learners' confidence to write independently. Therefore, a teacher has the responsibility to identify activities that promote students' writing ability. He/ she should also facilitate the overall practice of students' writing. As a facilitator, he/she comments on the incorrect agreements, improper use of articles, pluralization, and syntactic forms of students' sentences. He/she also gives feedbacks on drafts of a paragraph to maintain its unity, coherence and development. The teacher gives these comments and feedbacks while the students are revising their paragraphs. Students can also get feedback from their friends. They make an overall revision before they submit the final writing.

This process of scaffolding writing follows the stages of writing. It is a process of supporting students by making the tasks clear and simple for them. It motivates students to be committed to progressing their writing. To scaffold students, Bruner (1978) suggested some techniques that the teacher need to employ in the EFL classrooms. The techniques include motivating students' interests, simplifying the tasks, controlling the frustration of students, marking critical points, and correcting errors carefully.

The teacher of second or foreign language learners has to facilitate students learning till their students become more proficient (Diaz-Rico \&Weed, 2002). Scaffolding in teaching writing is practised in the way of giving verbal or written feedback for student writers in the process of writing. Peterson (2010) added that the teacher provides feedback on students' writing to support their writing development and nurture their confidence as writers. Hence, the teacher and 
students should work collaboratively to achieve students' writing skills development. When students become more efficient the guidance is removed gradually.

Thus, scaffolding writing is considered as an effective technique to teaching writing skills through combining it with stages of process writing. Therefore, in this study, the researchers are initiated to employ this technique to examine its effect on the paragraph writing skills of students in the Ethiopian context.

In Ethiopia, English has been taught and given much emphasis so that it is being taught as a subject, and it is serving as a medium of instruction for other subjects in secondary and tertiary levels of education. In the syllabi of secondary schools and universities, all English language skills are incorporated.

Although all the skills are equally important, students appeared to be much more deficient in writing as far as the researchers' experience shows. Particularly, at Meneguzer secondary school, Grade Nine students had difficulties in generating ideas, constructing sentences and organizing paragraphs. Consequently, it was believed that employing a different and innovative teaching writing technique was a paramount important approach to improve students' writing ability. Hence, the researchers were inspired to employ the scaffolding technique to teach writing skills for grade nine students to examine its effectiveness. Substantiating this, Vernon (2002) suggested that this technique can be implemented by combining it with the stages of writing in the process approach writing approach.

In this regard, there are global studies that investigated the effect of teacher scaffolding techniques on students' writing achievement. For instance, Vonna, et.al, (2015) in Pendidikan BahasaInggris University and Negeri Malang and Artini and Padmadewi (2019) at North Bali Bilingual School Singaraja made investigations. The results have shown that the scaffolding technique can significantly improve the students' writing achievement.

Similarly, this study was conducted to examine the effect of teacher scaffolding on students' paragraph writing skills in the Ethiopian context to attain the following objective. The general objective of this study was to examine the effect of teacher scaffolding on grade nine students' paragraph writing skills. The study specifically, attempted to answer the following research questions:

- Does teacher scaffolding have any effect on grade nine students' paragraph writing performance?

- Is there any significant difference between the experimental and control groups of the participants in their paragraph writing performance after the treatment?

- What is the experimental group students' reflection towards scaffolding on their paragraph writing performance?

\section{METHODOLOGY}

\section{A. Design of the Study}

A quasi-experimental research design was employed to examine the effect of teacher scaffolding on students' paragraph writing performance as it allows using the intact groups based on the availability of participants and the natural setting (Gass and Mackey, 2005). Besides, the study employed a mixed-method, especially the explanatory sequential mixed methods research approach (Creswell,2014).

\section{B. Participants of the Study}

The participants of this study were Grade Nine students, of the 2019/2020 academic year, from Meneguzer Secondary School, South Gondar, Amhara Region, Ethiopia. There were four sections of Grade Nine, 40 students in each class. A pretest on writing performance was given to all students in the four sections. Based on the students' mean score similarity, two sections were selected. They were assigned as experimental group and control group using the lottery method of random sampling technique. That is to mean, there were 40 students in each group. For the interview, six students were selected from the experimental group using a systematic random sampling technique.

\section{Data Gathering Instruments}

Test, having pretest and posttest, was used as a major data-gathering tool. The pretest was used to check the homogeneity level of participants in their writing performance, whereas, the posttest was used to measure the effect of teacher scaffolding on students' writing performance after the treatment. Both of them were prepared with similar procedures with the insight obtained from Heaton (1990). The researchers developed selected writing topics, specifically, 'Effects of drought' for pretest, and, 'Effects of deforestation' for posttest.

The time frame to write paragraphs on these topics was determined to be 80 minutes for each topic. Finally, to score the tests, there was a rubric to keep the consistency of scoring students' paragraphs. The analytic scoring rubric which was used for the writing tests had been designed in the range of points based on performance qualities.

A questionnaire was also used to examine the feelings of the students in the experimental group towards the role of scaffolding technique on their writing skills. The questionnaire included 12 close-ended items with 5 levelled Likert scales.

Besides, assessing the reflection of participants in the experimental group upon the effect of scaffolding on the writing progress, an interview was also used. The interview had 3 semi-structured items in an open-ended and chained format. The interview was delivered in the Amharic language, the student's mother tongue, for ease of communication to obtain sufficient data. 


\section{Data Collecting Procedures}

First, the quantitative data were collected. Then, the qualitative data collection followed. Accordingly, the treatment of teaching the experimental group about writing paragraphs was made before data collection. The lesson delivery which took an hour each day was made using a manual for teaching paragraph writing. Then, on the fourth day of the first week, the participants of the experimental group were required to write a paragraph on the topic: 'Effects of Smoking Cigarette'. After participants wrote the first draft, the researchers gave feedback on the content (relevance and subject knowledge) and organization (coherence, logical sequencing). After they wrote the second draft, then, feedback was given to them on the mechanics (spelling, punctuation) of their paragraph. This session took four hours in two days.

Next, on the first day of the second week, another practice of paragraph writing was held on the topic, 'The Effects of Drinking too much Alcohol.' In the process of writing, the researchers gave feedback on vocabulary richness and language use. In this regard, the focus of language use was on the usage of articles, word order, tenses, prepositions and sentence constructions concerning language use. Then, on the second school day, both experimental and control groups of students were instructed to write a paragraph on the topic, 'The Effects of Deforestation' as a posttest and the raters scored the participants' paragraphs similar to the pretest in two days. The task took two hours for writing and two hours to score the posttest by two raters.

On the third school day of the second week, the questionnaire was administered to the experimental group participants. Finally, the interview was delivered to the experimental group after filling the questionnaire on the same day. For the interview, samples were selected among the experimental group participants by the systematic random sampling technique. Six participants were chosen for this purpose.

\section{E. Methods of Data Analysis}

Explanatory sequential mixed methods of data analyses were used to analyze the test, questionnaire and interview data. The pretest data were analyzed through an Independent Sample t-test to check the homogeneity level of students in their writing performances. The scores of the posttest were also analyzed using Independent Sample t-Test to calculate the mean score difference between experimental and control groups. The questionnaire data were analyzed with frequency and percentage, whereas, the interview data were analyzed thematically.

\section{ReSUltS AND ANALYSIS}

\section{A. Analyses of the Pretest Results of the Experimental and Control Groups of Students}

The results of the pretest score of the experimental and control groups were analyzed through an independent sample t-test as follows.

TABLE 1

Pretest MEAN SCORE Results OF THE ExPERIMENTAL AND CONTROL Groups OF STUDENTS

\begin{tabular}{|l|l|l|l|l|l|}
\hline \multicolumn{1}{|c|}{ PRETEST MEAN SCORE RESULTS OF THE EXPERIMENTAL AND CONTROL GROUPS OF STUDENTS } \\
\cline { 3 - 7 } & Groups & $\mathrm{N}$ & Mean & Std. Deviation & $\begin{array}{l}\text { Std. Error } \\
\text { Mean }\end{array}$ \\
\hline \multirow{2}{*}{ Pretest } & Experimental & 40 & 23.88 & 14.046 & 2.221 \\
\cline { 2 - 6 } & Control & 40 & 22.40 & 15.679 & 2.479 \\
\hline
\end{tabular}

As shown in the above table, there were 40 participants in each of the experimental and control groups of students. In the pretest, their mean scores were 23.88 and 22.40 for the experimental and control groups, respectively. This implies that before the treatment of scaffolding, there was no significant difference between the writing performance of the experimental and control groups of students.

TABLE 2

ANALYSIS OF PRETEST SCORES OF THE EXPERIMENTAL AND CONTROL GROUPS OF STUDENTS

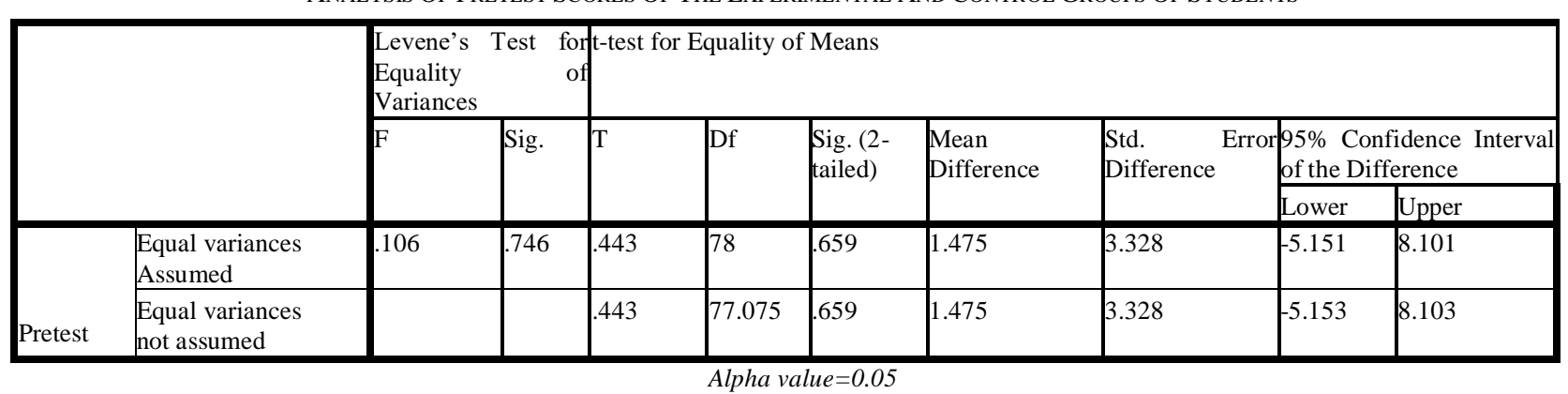

Regarding the assumption of homogeneity of variance, Pallant (2001) claimed that if a significant value of two groups is greater than 0.05 , the two groups have equal variance. Hence, based on the above Table2, the significant value of the two groups in their pretest was $\mathrm{p}=0.746$ that is greater than 0.05 . This means that the variability of the scores for each of the groups of students was similar. In other words, there was a homogeneous variance between 
experimental and control groups writing performance in their pretest since the analysis in Table 2, the sig. (2-tailed) value $=0.659$ was greater than 0.05 . Equal Variances were assumed. Therefore, there was no significant difference between the experimental and control groups of students regarding their writing performance before the treatment.

\section{B. Posttest Results of Experimental and Control Groups of Students}

The results of the posttest scores of the experimental and control groups of students were analyzed through an independent sample t-test as follows.

TABle 3
MeAns Score Results Of The EXPERIMENTAL AND CONTROL GROUPS OF Students In The PostTest

\begin{tabular}{|l|l|l|l|l|l|}
\hline \multirow{2}{*}{ Posttest } & Groups & $\mathrm{N}$ & Mean & Std. Deviation & Std. Error Mean \\
& Experimental & 40 & 31.38 & 13.770 & 2.177 \\
\cline { 2 - 6 } & Control & 40 & 24.15 & 14.517 & 2.295 \\
\hline
\end{tabular}

As this analysis reveals, the mean score of the posttest for the experimental group of students was 31.38 and 24.15 for the control group. This implies that there is a significant difference between the experimental and control groups of the participants in their paragraph writing performance after the treatment as the mean score results of the experimental group of students exceed the control group of students mean score result.

TABLE 4

ANALYSis Of POSTTEST SCORES OF EXPERIMENTAL AND CONTROL GROUPS OF STUDENTS

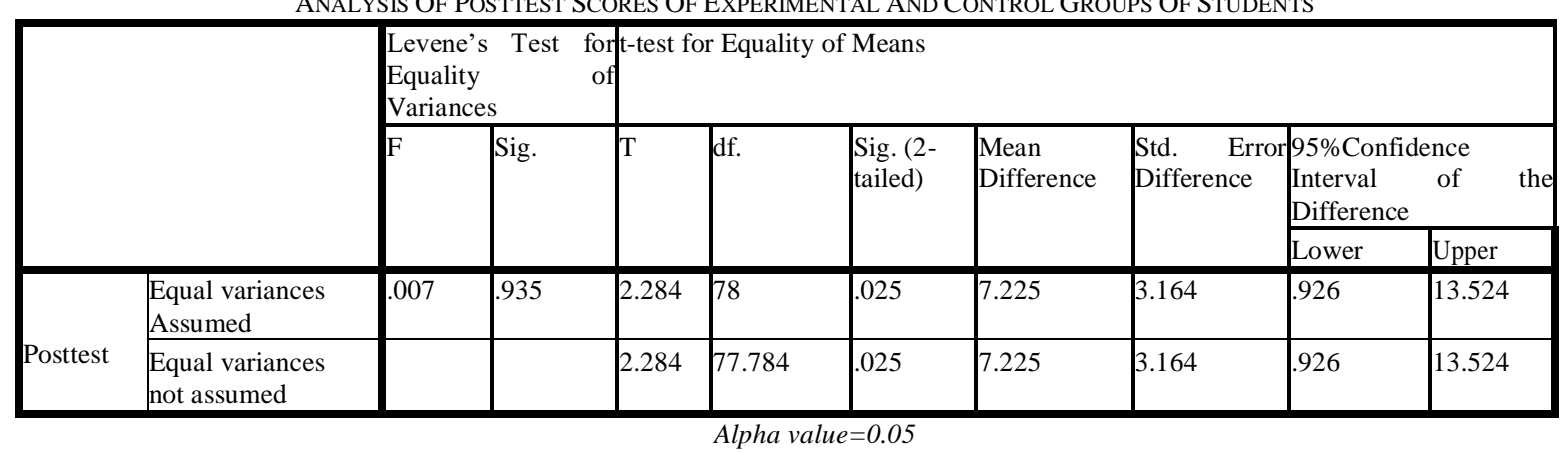

As the assumption of homogeneity of variances was checked in pretest scores of experimental and control groups of students, Levene's test for equality of variances was also checked in the posttest writing performance of the experimental and control groups of students. In this regard, Pallant (2001) stated that the experimental and control groups are varied if the significance value is $p=0.05$ or less. Therefore, in the current study the sig. (2-tailed) value is 0.025 which is lower than 0.05 that violates the assumption of the equality of variances. In other words, the violation of the assumption indicated that there was a significant difference between the experimental and control groups in their post-test writing performance. This implies that the experimental group performed better in the writing tasks than the control group of students.

\section{Analyses of Questionnaire Data}

The analysis of the questionnaire data intended to assess the reflection of the experimental group of students about the effect of teacher scaffolding on their writing performance is presented as follows. 
TABLE 5

QUESTIONNAIRE DATA ANALYSIS

\begin{tabular}{|c|c|c|c|c|c|c|}
\hline \multirow[t]{2}{*}{ No } & \multirow[t]{2}{*}{ Item } & \multicolumn{5}{|c|}{ Number of participants responded } \\
\hline & & 1 & 2 & 3 & 4 & 5 \\
\hline 1 & The teacher's support helped me to brainstorm ideas to develop a paragraph & 2 & 1 & 0 & 30 & 7 \\
\hline 2 & $\begin{array}{l}\text { The support I received from my teacher helped me to shape the topic sentence } \\
\text { of the paragraph }\end{array}$ & 0 & 0 & 1 & 5 & 34 \\
\hline 3 & $\begin{array}{l}\text { The paragraph writing process became easier due to my teacher's close } \\
\text { support. }\end{array}$ & 4 & 6 & 0 & 10 & 20 \\
\hline 4 & The support of the teacher helped me to organized ideas in writing paragraph & 0 & 0 & 0 & 8 & 32 \\
\hline 5 & $\begin{array}{l}\text { The teacher's support reduced difficulties of organizing ideas to develop } \\
\text { paragraph }\end{array}$ & 2 & 4 & 0 & 25 & 9 \\
\hline 6 & $\begin{array}{l}\text { The guidance the teacher gave me helped me keep the structure of my } \\
\text { paragraph. }\end{array}$ & 0 & 5 & 2 & 11 & 22 \\
\hline 7 & The support of the teacher helped me to keep the unity of the paragraph & 0 & 2 & 3 & 4 & 31 \\
\hline 8 & $\begin{array}{l}\text { The support informed me to use cohesive devices properly such as, first, next, } \\
\text { because, for example, as a result, but, etc. }\end{array}$ & 0 & 3 & 2 & 23 & 12 \\
\hline 9 & $\begin{array}{l}\text { The teacher's support has reduced my frustration of making errors in writing a } \\
\text { paragraph. }\end{array}$ & 3 & 2 & 0 & 27 & 9 \\
\hline 10 & $\begin{array}{l}\text { The teacher's support helped me use appropriate language to the intended } \\
\text { audience in my paragraph writing. }\end{array}$ & 1 & 2 & 1 & 14 & 22 \\
\hline 11 & In the writing process, the teacher's support helped me to revise my paragraph & 3 & 1 & 0 & 11 & 25 \\
\hline \multirow[t]{3}{*}{12} & My writing skill has been improved through the support of the teacher. & 0 & 2 & 1 & 32 & 5 \\
\hline & Total $=482$ & 15 & 28 & 10 & 200 & 229 \\
\hline & Percentage & 3.11 & 5.81 & 2.1 & 41.49 & 47.51 \\
\hline
\end{tabular}

According to the result of the questionnaire data analysis in Table 5 above, the respondents agreed that the teacher's support helped them to improve their writing skills. The analysis showed that the respondent's level of agreement on the effect of teacher scaffolding on their writing was found to be 41.49 per cent agreed and 47.51 per cent strongly agreed. To be specific, teacher scaffolding helped students in brainstorming ideas, organizing sentences to form paragraphs, in maintain unity and coherence of paragraphs and editing paragraphs. Moreover, participants' reflection of the effect of teacher scaffolding showed that the teacher's support reduced their difficulties of writing and frustration of making errors while writing a paragraph. Generally, the analysis of the questionnaire data indicates that teacher scaffolding was founded helpful for learners to improve their writing performance.

\section{Analyses of Interview Data}

The analysis of the participants' interview responses concerning the effect of teacher scaffolding on their writing performance showed that most of the participants improved their writing skills practically in the case of teacher scaffolding. Among the participants, student two $\left(\mathrm{s}_{2}\right)$ said "I have learned that a paragraph should deal on a single idea. The support of my teacher made me eager to develop unified sentences in a paragraph". Besides, $s_{5}$ in his part reported that the teacher scaffolding helped him to maintain coherence in the paragraph through using cohesive devices to join sentences such as cause and effect, contrast and addition cohesive devices. Moreover, $\mathrm{s}_{1}$ and $\mathrm{s}_{4}$ reported that the teacher scaffolding improved their difficulties to use correct spelling, punctuation, capitalization, choice of words and sentence structures.

Additionally, the interviewees' reflections showed that the teacher's support motivated them to practice writing skills. It also shaped them to rely on their writing ability. In this regard, $S_{6}$ forwarded his feeling as "I could not write a meaningful sentence before this treatment. When I start to write about a given topic, I become confused about what to start and how to organize words in a sentence. However, after I got this treatment, I was able to write a paragraph by combining sentences. Now, I am motivated to write a paragraph."

Generally, the analysis of the interview revealed that the teacher's close support of students' writing has contributed to improving their writing performance and being motivated in writing. This indicates that teacher scaffolding helped students to promote their writing skills.

\section{DISCUSSION}

The results are discussed in a way to answer the raised research questions. That is to say, so as to answer the research questions posed, the findings obtained from each data analysis were triangulated and then concluded as follows.

Regarding the effect of teacher scaffolding on students' writing performance, the post-test means score result of the experimental group of students was founded greater than the control group mean score result. Besides, the findings of the questionnaire and interview data analyses that were intended to examine the respondents' reflection about the treatment of teacher scaffolding substantiate this finding that the teacher scaffolding has improved students writing performance. Hence, the practice of teacher scaffolding has a positive effect on students' writing. This finding agrees with the studies of Katilie (2003), Vereappan et.al. (2011), Yangrifqi (2012), Solikhah (2012), Laksmi et al (2015) that teacher scaffolding has a positive effect on students wring performance. 
The second research question was about investigating whether there was a significant difference between the experimental and control groups of participants in their writing performance. In this regard, the means scores of the posttest were 31.38 and 24.15 for the experimental and control groups, respectively. Similarly, the observed significance value is lower than the alpha value i.e. sig. value $/ 2$-tailed/ $=0.025$ less than $\mathrm{p}=0.05$ so that the assumption of 'Equal variances not assumed' had been checked. Therefore, in the posttest, the two groups were founded to be significantly different. This means that the experimental group of learners showed better writing achievement than the control group of students. Substantiating this, the findings of both the questionnaire and the interview data analyses that intended to check respondents' reflection about the effect of teacher scaffolding revealed that the experimental group participants made better performance than the control group in their writing skills. Consequently, the finding of the questionnaire and the interview data analyses supported the finding of the posttest mean score results.

The third research question was intended to assess the feelings of the experimental group of participants towards the effect of teacher scaffolding on their paragraph writing performance. In response to this question, the findings of both the questionnaire and interview data analyses revealed that there was a positive effect of teacher scaffolding on their writing performance. Therefore, the experimental group of students felt that using teacher scaffolding could help the students to improve their writing skills effectively. The teacher scaffolding technique of teaching writing motivated the students to practice writing skills actively and confidentially.

Generally, in the discussion of the findings, teacher scaffolding had a positive effect on Grade Nine students' paragraph writing skills. The result of the study showed that teacher scaffolding has contributed better than the conventional method of teaching paragraph writing skills of students. As a result, the students were found motivated to practice more their writing skills.

\section{CONCLUSION}

In general, it can be concluded that implementing teacher scaffolding can improve the students' paragraph writing skills. This is because students who were treated by the teacher scaffolding achieved better than the students who were not treated by the teacher scaffolding in their paragraph writing. This implies that using teacher scaffolding has a significant effect on students' writing performance when compared with the conventional method of teaching writing. It can also motivate students to practice their writing skills independently.

\section{ACKNOWLEDGMENTS}

The authors would like to thank the students of Meneguzer Secondary School who participated in the study

\section{REFERENCES}

[1] Bruner, J. (1978). The role of dialogue in language acquisition. In A. Sinclair, R. J. Jarvella and W. Levelt (Eds.), The child's concept of language (241-255). New York: Springer Verlag.

[2] Creswell, J.W. (2014). Research Design Qualitative, Quantitative, and Mixed Methods Approaches (4thed.). Thousand Oaks, CA: Sage.

[3] Diaz-Rico, L.T., \& Weed, K.Z. (2002). The cross-cultural, language, and academic development handbook: A complete K-12 reference guide (2nd ed.). Boston: Ally \& Bacon.

[4] Durga S.S. and Rao C. S. (2018). Developing Students' Writing Skills in English - A Process Approach. Retrieved from ISSN: 2456-8104 http://www.jrspelt.com Issue, 6 (2). Accessed on June $1^{\text {st, }} 2020$.

[5] Gass, M. and Mackey, A. (2005). Second Language Research Methodology and Design.Mahwah, N.J.: Lawrence Erlbaum.

[6] Heaton, J. (1990). Writing English Language Tests. Longman New York.

[7] Katilie, N. (2003).Improving Students' Writing by Using Scaffolding Strategy in the Process of Writing at SLTP Negeri 3 Tolitoli. Thesis. Malang: PPS UM Malang.

[8] Laksmi, E.D. et al (2015). The Effect of Scaffolding Techniques on Students' Writing Achievement. Journal of Pendidikan Humaniora: Pendidikan BahasaInggris-Universitas Negeri Malang, 3 (1) 227-233.

[9] Padmadewi, N. N. and Artini, L.P. (2019). Using Scaffolding Strategies in Teaching Writing For Improving Student Literacy in Primary School. Advances in Social Science, Education and Humanities Research: Atlantis Press, 178,156-160.

[10] Pallant, J. (2001). SPSS Survival Manual. A step by step guide to data analysis using SPSS for windows version 10 and 11.

[11] Peterson, S.S. (2010). Writing across the curriculum: All teachers teach writing (2nded.). Winnipeg, MB: Portage \& Main Press.

[12] Veerappan, et al.(2011).The Effect of Scaffolding Technique in Journal Writing among the Second Language Learners. Journal of Language Teaching and Research, 2 (4), 934-940. Finland: Academy Publisher.

[13] Vernon, L. (2002). The Writing Process: A Scaffolding Approach. Retrieved from (HTTP:www.Wm.edu/TTAC/ packets/writing process.pdf, Accessed on April 9th, 2020.

[14] Solikhah (2012). Implementing Scaffolding Strategy to Improve the Ability in Writing Exposition of Grade XI Students of SMAN Bangil. Unpublished. Thesis. Malang: The State University of Malang.

[15] Vonna Y., Mukminatien N. \& Laksmi E. D. (2015). The Effect of Scaffolding Techniques on Students' Writing Achievement. Pendidikan Bahasa Inggris-Universitas Negeri Malang. Retrieved from http://journal.um.ac.id/index.php/jphISSN: 2338 8110/ISSN: 2442-3890 Accessed on September $23^{\text {rd }} .2020$

[16] Yangrifqi, N. (2012). The Effectiveness of Scaffolds and Conferencing on Senior High School Students'Ability in Writing Narrative and Descriptive Texts. Unpublished Thesis. Malang: State University of Malang. 


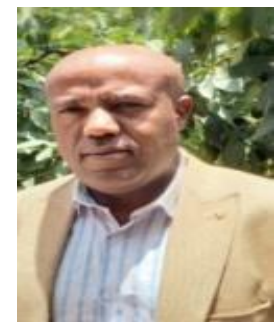

Simachew Gashaye has received a Bachelor's of Arts in Teaching English from Bahir Dar University, Ethiopia in 2000. He has earned his Master of Arts in Teaching English as Foreign Language (TEFL) from Addis Ababa University, Ethiopia, in 2005. He has also received his Doctor of Philosophy in Teaching English as a Foreign Language from the same University in 2012. In addition to receiving these degrees, he has been promoted to the academic rank of Associate Professor of Teaching English as Foreign Language because of his research publications and effective teaching experience in the field in different universities.

Currently, he is offering different courses to the $\mathrm{PhD}$ and MA students in the TEFL programmes. Moreover, he is supervising such postgraduate students in the field at Debre Markos University, Ethiopia.

Apart from his teaching and research experiences, Simachew has served Debre Markos University as:

- Vice President for Research and Community Service (2013-2017),

- Director for Continuing Education (2007-2009),

- Board Member of the University Business Enterprise and

- Member of Senate Standing Committees of the University.

Regarding his research interest area, Simachew has engaged mainly in language teaching methods and language testing. He has been publishing articles in different journals. To mention some,

$\checkmark \quad$ International Journal of Current Research Volume 9(12), 9106 - 9111, December 2019;

$\checkmark \quad$ Indus Foundation for Research and Social Welfare, 9(11), 41-50, November 2019;

$\checkmark \quad$ Journal of Education and Practice, 10 (22), 23-40, August 2019.

$\checkmark \quad$ Theories and Practice in Language Studies.10 (4), 372-378.

$\checkmark$ International Journal of English Language and Literature Studies, 9(2), 106-120.

$\checkmark$ Theories and Practice in Language Studies.10 (6), 623-631.

$\checkmark \quad$ Theories and Practice in Language Studies. 11(7), 780-788.

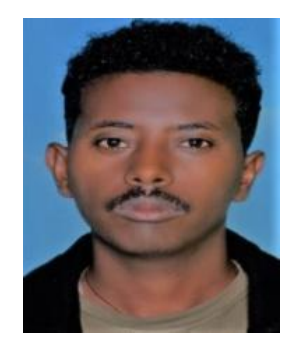

Belyihun M. Lakew was born in Amhara regional state, Ethiopia in 1993. He attended his primary school in Fogera woreda, at Alember primary school and secondary school at Woreta secondary and preparatory school. Then, he joined Debre Markos University in 2011 and completed his BA degree in English Language and Literature in 2016. He received his MA degree in Teaching English as Foreign Language (TEFL) from Debre Markos University in 2020.

$\mathrm{He}$ has been teaching English in Fogera woreda secondary and preparatory schools. He has been researching with Dr Simachew Gashaye (PhD, Assoc.Prof.in TEFL). 